\title{
Knowledge and Partnerships for Sustainability and Equality
}

\author{
Adam Habib
}

We live in interesting, but dangerous times; our world today is as unequal as it was before World War I and II. We are increasingly becoming as socially and politically polarized as we were then. Right-wing populist and nativist parties stalk all of our lands, deepening divides among our communities both nationally and internationally. Political and economic elites are paralyzed about what to do, or at least have not been able to marshal the will to undertake what needs to be done.

And yet, what needs to be done is known, or at least should be known. At the heart of the crisis today is the issue of social justice. Yes, we have taken millions out of poverty, but millions still remain mired in misery. As important, if not more threatening to our collective future, is inequality. So many have too little because so few have too much. This is the popular realization of our time, and it is why globalization has come under attack. It is why populist and nativist parties have been able to mobilize on the foundation of this popular resentment. But they, of course, have no answers as they propel us into a retreat to nativism and chauvinism of all kinds.

This deepening of human divides imperils humanity. Climate change, public health, renewable energy, inequality, and social and political polarization are transnational challenges that require the global community to cohere and act as one. Yet, this is not possible if the divides continue to deepen. Only if we build the bridges of human solidarity will we survive as a species. How to do this is one of the defining questions of our era and should be at the heart of how we reimagine universities in a post-pandemic world.

Universities are meant to assist in addressing the challenges of the historical moment. Inequality is perhaps the most significant of these because it politically and socially polarizes society and undermines our global and national capabilities to

\footnotetext{
A. Habib ( $\square)$

School of Oriental and African Studies (SOAS) - University of London, London, UK

e-mail: soasdirector@soas.ac.uk 
address the myriad of transnational challenges that we confront. But, addressing it requires universities to go beyond simply researching the challenges and proposing appropriate policies. Instead, it requires the university to transform its very essence: whom it brings to the university, how it teaches them, whom it employs, how it publicly expresses itself, and how it partners with other institutions around the world.

Essentially, if it is to address inequality, the university must undertake two distinct activities. First, it has to ensure that students from poor and marginalized communities are allowed in, provided with a quality education and graduate so as to enable the social mobility that addresses inequality within the society. But inequality is as much a feature of the global as it is of the local. This is why the university has to undertake a second activity; it has to partner with other similar institutions around the world to undertake the first activity on a global scale. The second activity also has to be undertaken so as to provide the human resource capacities and knowledge to address transnational challenges.

If this Covid-19 pandemic has demonstrated anything, it is that even though our challenges are global, local context and knowledge matter more than ever. Notice, for example, how the different parts of the globe battled with strategies for mitigating Covid-19, and how strategies such as a lockdown have had differential impacts across the globe. Thus, we require high quality institutions and human resource capacities across the world to address both global challenges and their local manifestations. Moreover, unless institutions in the global South are simultaneously able to innovate in their local context and also able to generate ideas and solutions to global problems from the perspective of their spatial and social specificity, we will not have reached effective and lasting solutions to our transnational challenges. We need more inventors, scientists, technologists, social actors, academics and students-in short innovators - to develop and adapt technologies for their circumstances. For this to happen, we need enabling environments. We need universities and vocational colleges that train, research and innovate; companies that are entrepreneurial; incubators that can nurture new technologies; and venture capital networks that can sponsor these initiatives. Essentially, as long as capable institutions and capacities do not exist across the world and in different contexts to contain global challenges like infectious diseases, the world will remain vulnerable to the next crisis.

The Sustainable Development Goals (SDGs) - those goals collectively recognized by the global community-recognize this. Goal 4-Quality Education-calls on us to: "Ensure inclusive and equitable quality education and promote lifelong learning opportunities for all". It proceeds by specifically calling for the expansion of scholarships in the STEM fields for developing countries.

By 2020, substantially expand globally the number of scholarships available to developing countries, in particular least developed countries, small island developing States and African countries, for enrolment in higher education, including vocational training and information and communications technology, technical, engineering and scientific programmes, in developed countries and other developing countries.

Goal 17 then states: "Strengthen the means of implementation and revitalize the global partnership for sustainable development". But, what if these two goals are in tension with each other. What if Goal 4 is undertaken in a manner that undermines 
Goal 17. Indeed, has this not been the case in the last few decades? In this era of globalization, we have had more global partnerships, more scholarships and more mobility across the world. Yet, this has also been the period in which brain drain has dramatically escalated, and institutions have weakened in some parts of the developing world.

This is definitely the case in African higher education. Of course, this dynamic is not the only causal factor in the weakening of African universities. They were irreparably damaged by structural adjustment to public policies in the 1980s, inspired by international development agencies that called for the prioritization of primary and secondary education, and the underfunding of universities. The idea was that tertiary education would be undertaken in the developed world. While this policy was partially reversed in the subsequent decades, the damage had been done. Moreover, our global partnership model has not fundamentally changed since the 1980s. Its methodology is to direct scholarships to talented individuals in the developing world and have them go to Europe and North America to acquire tertiary education. The assumption is, of course, that these students will return home. But, the evidence of the last few decades is that this is not the case. When these students go there, life happens. They fall in love, they have families, they get jobs and stay. At a recent conference on the diaspora at the African Union in Addis Ababa, it was demonstrated that more than $80 \%$ of students do not return. And this does not only speak to the African experience. Indeed, it is typical of much of the experiences of the developing world, including India and China, the latter having reversed the trend only recently.

The corollary of this in the developing world is that institutions have been weakened, human resource capacities are weakening or are not being developed, and inclusive development is being compromised. Of course, some among us speak of brain circulation rather than brain drain, and the importance of remittances to the developing world. But, if we are honest, we would recognize that these are weak countertrends that do not fundamentally change the negative institutional and structural dynamics that accompany the brain drain and compromise inclusive development.

It must be stressed that this is not only a problem for the developing world. It is as much a problem for the developed world. Herein lies the dilemma. As human resource capacities decline in the developing world, so does our ability to deal with the structural challenges of our era-which are also transnational. The most dramatic example of this is the coronavirus which has become a global pandemic. Imagine a pandemic caused by a pathogen that is equally infectious but even more deadly. The consequences would be devastating for the world. The only way we have a fighting chance to avoid this is for us to have the institutional infrastructure and human resources in both the developed and developing world to stem the challenge at its source, wherever it emerges. Yet, our global partnership methodologies undermine this, in practice if not in intent.

It should be noted that the argument here is not for some autarchic retreat into nationalism, nationhood and ethnicity. This is not possible; the human spirit has simultaneously an impulse to wander and explore-globalise-and identify and familiarize-localise if there is need for a term to describe this. These are not mutually exclusive agendas as populist and nativist parties tend to suggest. Instead, they 
can be complementary elements of human existence. Every one of us has families and communities whom we identify with and whom we love, but it need not dissuade us from caring about what happens to other members of the community elsewhere in the world. We can love our families and community networks and still practice human solidarity outside our familial networks. It is possible to be both local and global. Indeed, this is essential in this era if we are meant to survive as a human species.

What is being advocated is a new methodology of global partnership, one that is more rooted in institutions than individuals. In higher education, this would require joint teaching programs and split-site scholarships that would enable students to gain scientific knowledge, develop a global consciousness, have access to new equipment and funding networks, and yet be sufficiently rooted in institutions of the developing world to allow for this knowledge and skills to be deployed within their local contexts. Such a methodology would also allow students from the developed world to have the opportunity to visit the developing world, where institutional settings would exist that can host them, so that they too can understand the contextual circumstances of the developing world, and develop skills and knowledge that are more universally applicable.

This may go against the grain of the strategic plans of some universities in the developed world. Some of the more high-ranking of our institutions believe that their brands would be diluted by joint teaching agendas. They believe that they are here to train the scientists and knowledge brokers of our world. But they delude themselves. Whatever their scientific strengths, however recognized their academic cohort may be, however talented their students are, their contribution to our world is limited by the institutional arrogance that they matter more than others. In their legitimate desire to be competitive and their idiocy in believing that this needs to translate into a chauvinistic protection of an institutional brand, they undermine their own institutional mission. They have forgotten that great science needs to be accompanied by contextual understanding to have a dramatic impact.

The economic elites who sit in Davos or the researchers who sit behind their laptops in the coffee shops of the academic villages surrounding the great universities of the developed world cannot, on their own, solve the challenges of our era. They need an understanding of the context of the developing world, which is only possible through global teams of researchers and institutions coming together and deploying their collective knowledge, skill sets, and understanding to develop contextually relevant technologies and solutions to the challenges of our time. What we effectively need is an equitable global partnership of institutions that are rooted in the diversity of our community and deployed across all of our countries. This is a global agenda that is equitable, socially just, sustainable and universally relevant for this era.

What is being called for is an academy of commons. For centuries, we have pretended that science has no boundaries. Yet, every day we establish institutional and national boundaries that constrain science, knowledge and innovation. We need to seriously break down these boundaries, borrow and learn from each other in a collaborative and equal manner. Lessons learnt and innovations developed in each of our contexts could lead to changes in the rest of the world. We need a global academy 
of commons that understands the contextual nature of technological advances and how innovation can play a part in creating a more inclusive world.

Such a global academy could be a bridge of hope between an unequal and fractured past and present and an inclusive, collective future. But for it to become such a bridge of hope, we need to have the courage to ask the hard questions about our practices and improve them where we can. We have the intellectual resources across disciplines and institutions that can assist us in thinking through innovation more carefully to ensure that it is contextually grounded and inclusive. By doing so, we will genuinely address the inequalities and challenges of our time, creating a more socially inclusive and humane world.

Adam Habib is an academic, researcher, activist, administrator, and public intellectual. He is the Director of the School of Oriental and African Studies (SOAS) and has just completed his tenure as the Vice-Chancellor and Principal of the University of the Witwatersrand (Wits) in South Africa. He is the author of South Africa's Suspended Revolution: Hopes and Prospects, which investigates the country's transition to democracy, as well as Rebels and Rage: Reflecting on \#FeesMustFall, which provides an insight into the recent student uprisings.

Open Access This chapter is licensed under the terms of the Creative Commons Attribution 4.0 International License (http://creativecommons.org/licenses/by/4.0/), which permits use, sharing, adaptation, distribution and reproduction in any medium or format, as long as you give appropriate credit to the original author(s) and the source, provide a link to the Creative Commons license and indicate if changes were made.

The images or other third party material in this chapter are included in the chapter's Creative Commons license, unless indicated otherwise in a credit line to the material. If material is not included in the chapter's Creative Commons license and your intended use is not permitted by statutory regulation or exceeds the permitted use, you will need to obtain permission directly from the copyright holder. 